DOI

\title{
КЛІНІЧНИЙ ПЕРЕБІГ ІНФАРКТУ МІОКАРДА З АНГІОГРАФІЧНО ІНТАКТНИМИ ТА МАЛОЗМІНЕНИМИ ВІНЦЕВИМИ АРТЕРІЯМИ У ЖИТЕЛІВ ГІРСЬКИХ ТА РІВНИННИХ НАСЕЛЕНИХ ПУНКТІВ ЗАКАРПАТТЯ
}

\author{
๑О. В. Устич
}

\section{ДВНЗ «Ужгородський національний університет»}

\begin{abstract}
РЕЗЮМЕ. Проаналізовані дані пацієнтів з інфарктом міокарда на фоні ангіографічно нормальних та незначно змінених вінцевих артерій у жителів різних висотних регіонів Закарпаття. Горяни були молодшими та мали більші розміри задньої стінки лівого шлуночка, правого шлуночка та лівого передсердя. Гірські мешканці рідше зверталися за медичною допомогою та частіше навіть не лікувалися при наявності загрозливих симптомів з боку серцево-судинної системи.

КЛЮчОВІ СЛОВА: інфаркт міокарда, інтактні вінцеві артерії, незначно змінені вінцеві артерії, гірські регіони.
\end{abstract}

Вступ. Інфаркт міокарда з ангіографічно нормальними вінцевими артеріями (IMАНВА) було визнано більше ніж 60 років тому, в час, коли коронароангіографія (КАГ) була ще невідома. Після появи КАГ стали виявляти все більше пацієнтів з IM на фоні HВА. У деяких пацієнтів знаходять незначне та помірне ураження ВА. Проте багато з цих пацієнтів дійсно мають ангіографічно нормальні BA [1-4]. IMAНВА зазвичай виникає у віці близько 50 років [5]. У пацієнтів можуть бути відсутні напади стенокардії в анамнезі, перенесені IM, фактори ризику ішемічної хвороби серця (IXC) [6]. Симптоми та електрокардіографічні (ЕКГ) зміни $\epsilon$ схожими з IM на фоні атеросклеротичного ураження ВА, але ділянки ураження, як правило, $є$ меншими [7]. Швидкість ускладнень після IM, таких як злоякісні аритмії, серцева недостатність (СН), артеріальна гіпертонія (АГ) $є$ нижчою та довготривалий прогноз є сприятливішим $[7,8]$. Приблизно у $6 \%$ пацієнтів з гострим IM та у $10 \%$ пацієнтів віком молодше 35 років з гострим IM виявляють НВА [9-12]. До епохи тромболітичної терапії̈іх виявляли у 1-3\%, після цей відсоток зріс до $15 \%[2,13]$, можливо через більше число ангіографічних процедур і зменшення часу між КАГ та тромболізисом оклюзивної ВА. Всі дослідження пацієнтів з гострим IM та AНBA показують, що такі пацієнти є молодшими (до 40 років), без загруднинного болю в анамнезі, без порушень гемостазу [14], без факторів ризику, крім куріння [15]. у жінок асоціюється з вживанням оральних контрацептивів та вагітністю [7].

IMAНВА можна поділити на 4 групи залежно від факторів ризику та ангіографічних змін:

1. Нема ФР та нормальні ВА;

2. Наявні ФР та нормальні ВА;

3. Нема ФР з незначно ураженими ВА;

4. Наявні ФР з незначними ураженнями ВА.

Поняття «нормальні» ВА включає відсутність внутрішньосудинних відхилень, гемодинамічно незначимі стенози (незначно уражені - $<30 \%$ та помірно уражені - 30-50 \%).

Було запропоновано декілька гіпотез для пояснення феномену IMAНВА. Можливі механізми розвитку включають коронарний вазоспазм [16], коронарний тромбоз in situ чи емболізацію зі спонтанним лізисом тромба $[7,15]$, вживання кокаїну, розшарування аорти, гіперкоагуляційні стани, аутоімунні васкуліти, отруєння оксидом вуглецю [17] чи гострий міокардит, особливо інфекційний [18-20]. Нещодавно було запропоновано механізм розвитку виникнення судинної дисфункції ендотелію пов'язувати з тютюнопалінням та вживанням кокаїну [21-23].

Мета дослідження. Метою нашого дослідження було вивчення особливостей клінічного перебігу інфаркту міокарда у пацієнтів, що $є$ мешканцями різних висотних регіонів Закарпаття.

Матеріал і методи дослідження. Досліджувану групу складали 65 пацієнтів з IM в анамнезі, які перебували на лікуванні у Закарпатському обласному клінічному кардіологічному диспансері (ЗОККД) у період із січня 2011 року по січень 2016 року, у яких під час КАГ були виявлені інтактні та гемодинамічно незначно уражені ВА. Основну групу (ОГ) склали 22 пацієнти, корінні мешканці гірської зони Закарпаття (медіана віку $(49,23 \pm 1,67)$ років). Контрольна група (КГ) включала 43 пацієнти, які мешкали у рівнинних населених пунктах Закарпаття (медіана віку $(57 \pm 1,82)$ років). Діагноз ІМ був підтверджений за допомогою маркерної діагностики IM, ЕКГ-змін та виявлення порушення руху стінок ЛШ на ехокардіограмі (ЕхоКГ). При аналізі враховували наступні показники: вік, стать, місце проживання (гірська чи рівнинна зона), клінічні особливості захворювання, наступні лабораторні показники: швидкість осідання еритроцитів (ШОЕ), рівні гемоглобіну (Нв), трансаміназ крові (АлАТ, АсАТ), креатиніну, потромбінового індексу (ПІ), міжнародного нормалізаційного співвідно- 
Огляди літератури, оригінальні дослідження, погляд на проблему шення (МНC), гематокриту; дані електрокардіографії (ЕКГ), холтерівського моніторування, коронароангіографії. Статистичну обробку даних проводили за допомогою програми Microsoft Excell 2010.

Результати й обговорення. У обстежених хворих з IMAIBA отримали такі середні показ-

ники: вік на момент поступлення у стаціонар $(54,68 \pm 1,41)$ р., вік на момент IM - $(51,88 \pm 1,51)$ р., час, що минув з моменту IM - $(2,68 \pm 0,52)$ р., тривалість стенокардитичних проявів $(0,97 \pm 0,829)$ р., тривалість ГХ - $(8,35 \pm 0,61)$ р. Клінічні особливості груп пацієнтів наведені в таблиці 1.

Таблиця 1. Розподіл хворих з ІМ на фоні ангіографічно інтактних та малозмінених ВА за групами

\begin{tabular}{|c|c|c|}
\hline Групи порівняння & ОГ $(n=22)$ & $\mathrm{K} \Gamma(\mathrm{n}=43)$ \\
\hline \multicolumn{3}{|c|}{ За статтю } \\
\hline Чоловіки & 18 & 29 \\
\hline Жінки & 4 & 14 \\
\hline \multicolumn{3}{|c|}{ За віком на момент поступлення } \\
\hline$\geq 50$ років & 7 & 31 \\
\hline$<50$ років & 15 & 12 \\
\hline \multicolumn{3}{|c|}{ За віком виникненя IM } \\
\hline$\geq 50$ років & 11 & 34 \\
\hline$<50$ років & 11 & 9 \\
\hline \multicolumn{3}{|c|}{ За часом, що минув з моменту IM } \\
\hline Більше 1 року & 13 & 18 \\
\hline Менше 1 року & 9 & 25 \\
\hline За наявністю стенокардії & 9 & 20 \\
\hline За наявністю ЦД в анамнезі & 13 & 22 \\
\hline За наявністю фібриляції передсердь в анамнезі & 2 & 8 \\
\hline \multicolumn{3}{|c|}{ За даними КАГ } \\
\hline Інтактні ВА & 12 & 19 \\
\hline Малозмінені ВА & 10 & 24 \\
\hline Правий тип & 15 & 31 \\
\hline Лівий тип & 3 & 7 \\
\hline Збалансований тип & 4 & 5 \\
\hline \multicolumn{3}{|c|}{ За наявністю перенесеного IM } \\
\hline Q-IM & 13 & 23 \\
\hline $\mathrm{He}-\mathrm{Q}-\mathrm{IM}$ & 9 & 20 \\
\hline \multicolumn{3}{|c|}{ За показникам ФВ } \\
\hline$\geq 50 \%$ & 16 & 25 \\
\hline$<50 \%$ & 6 & 18 \\
\hline
\end{tabular}

IM нижньої стінки лШ було виявлено у 7,7 \% осіб, ІМ передньої та передньо-перетинкововерхівкової локалізацій - у 7,3 \% та 6,1 \% осіб відповідно. Якщо у горян дещо частіше виявляли нижній IM, то серед мешканців рівнинних населених пунктів - IM передньо-перетинкововерхівкової локалізації, проте достовірної різниці за жодною з ділянок локалізації ІМ між цими групами виявлено не було (табл. 2)

При порівнянні пацієнтів гірської (група 1) та рівнинної зон (група 2) було виявлено достовірну різницю. Середній вік горян на момент виник- нення ІМ був майже на 9 років меншим, ніж у жителів рівнини - $(46 \pm 1,33)$ проти $(54,9 \pm 2,04)$ років ( $p=0,0005)$. Тривалість проявів стенокардії також була вищою у рівнинних мешканців - $(1,33 \pm 0,07)$ проти $(0,13 \pm 0,03)$ років відповідно у порівнювальній групі $(p<0,05)$. Гіпокінез передньо-перетинкової стінки та верхівки ЛШ виявляли у 14 та 11,6 \% пацієнтів контрольної групи та не виявили у жодного пацієнта з основної групи $(p=0,03)$. Аналіз внутрішньосерцевої гемодинаміки не виявив істотних відмінностей, за винятком більших розмірів ЗСлш, лП та ПШ у пацієнтів з гірської зони (табл. 3). 
Огляди літератури, оригінальні дослідження, погляд на проблему

Таблиця 2. Характеристика обстежених хворих залежно від локалізації перенесеного інфаркту міокарда

\begin{tabular}{|c|c|c|c|c|c|c|}
\hline \multirow[t]{2}{*}{ Локалізація перенесеного IM } & \multicolumn{2}{|c|}{$\begin{array}{c}\text { Мешканці гірських } \\
\text { населених пунктів } \\
(n=112)\end{array}$} & \multicolumn{2}{|c|}{$\begin{array}{c}\text { Мешканці рівнинних } \\
\text { населених пунктів } \\
(n=134)\end{array}$} & \multicolumn{2}{|c|}{$\begin{array}{c}\text { Загальний показник } \\
(\mathrm{n}=246)\end{array}$} \\
\hline & $\mathrm{n}$ & $\%$ & $n$ & $\%$ & $n$ & $\%$ \\
\hline IМ передньої стінки ЛШ & 6 & 5,4 & 12 & 8,96 & 18 & 7,3 \\
\hline Інфаркт міокарда нижньої стінки ЛШ & 8 & 7,1 & 11 & 8,2 & 19 & 7,7 \\
\hline $\begin{array}{l}\text { Інфаркт міокарда задньої та бокової } \\
\text { стінок лш }\end{array}$ & 5 & 4,5 & 8 & 5,97 & 13 & 5,3 \\
\hline $\begin{array}{l}\text { IМ передньо-перетинково-верхівкової } \\
\text { локалізації }\end{array}$ & 4 & 3,6 & 11 & 8,2 & 15 & 6,1 \\
\hline
\end{tabular}

Примітка. $n$ - кількість осіб у групах, IM - інфаркт міокарда, ЛШ - лівий шлуночок

Таблиця 3. Показники внутрішньосерцевої гемодинаміки у досліджуваних групах

\begin{tabular}{|l|c|c|}
\hline \multirow{2}{*}{ Показник } & \multicolumn{2}{|c|}{ Величина показника } \\
\cline { 2 - 3 } & основна група & контрольна група \\
\hline ФВ, \% & $52,64 \pm 1,95$ & $52,39 \pm 1,26$ \\
\hline МШП, см & $1,14 \pm 0,03$ & $1,09 \pm 0,02$ \\
\hline ЗСЛШ, См & $1,24 \pm 0,03^{*}$ & $1,0 \pm 0,02^{*}$ \\
\hline ЛП, См & $4,06 \pm 0,1^{*}$ & $3,8 \pm 0,08^{*}$ \\
\hline ПШ, См & $2,7 \pm 0,07^{*}$ & $2,5 \pm 0,06^{*}$ \\
\hline Е/А & $0,9 \pm 0,06$ & $0,8 \pm 0,02$ \\
\hline
\end{tabular}

Примітка. ФВ - фракція виходу, МШП - міжшлуночкова перетинка, ЗСлш - задня стінка лш, лП - ліве передсердя, ПШ - правий шлуночок; відмінності вірогідні на рівні * $0<0,05$

Також було виявлено, що жителі гірської місцевості рідше зверталися до лікарів та частіше навіть не лікувалися при наявності загрозливих

симптомів з боку серцево-судинної системи, що показано рисунку 1.

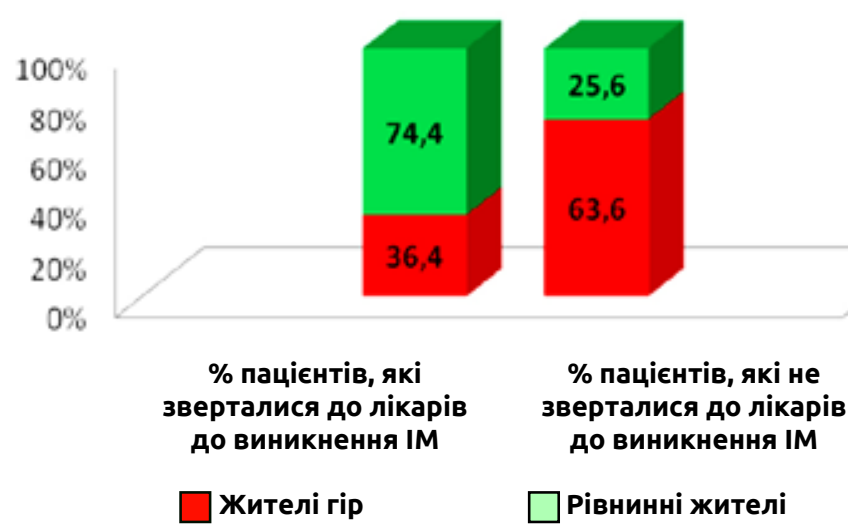

Рис. 1. Частота звернень пацієнтів за медичною допомогою до моменту виникнення IM.

Висновки. 1. Обстежені нами гірські жителі були майже на 9 років молодшими від мешканців рівнинних населених пунктів Закарпаття.

2. У горян виявляли достовірно більші розміри ЗС ЛШ, ПШ та ЛП.

3. Жителі гірських населених пунктів рідше зверталися за медичною допомогою та частіше навіть не лікувалися при наявності загрозливих симптомів з боку серцево-судинної системи.
Перспективи подальших досліджень. Для розв'язання проблеми, висвітленої у роботі, потрібна активна санітарно-освітня робота серед населення області, особливо серед мешканців гірських регіонів, залучення ЗМl, своєчасна оцінка ступеня ризику та прогнозу захворювання, призначення адекватного алгоритму лікування. 


\section{ЛІТЕРАТУРА}

1. Alpert J. S. Myocardial Infarction With Angiographically Normal Coronary Arteries / J. S. Alpert // Arch Int Med. - 1994. - № 154. - P. 265-269.

2. Characteristics And Prognosis Of Myocardial Infarction In Patients With Normal Coronary Arteries / P. Ammann, S. Marschall, M. Kraus [et al.] // Chest. - 2000. № 117. - P. 333-338.

3. Normal Angiogram After Myocardial Infarction In Young Patients: A Prospective Clinical-Angiographic And Long-Term Follow-Up Study / J. A. Fournier, A. SanchezGonzalez, J. Quero [et al.] // Int J Cardiol. - 1997. - № 60. P. 281-287.

4. Recurrent Myocardial Infarction With Angina And Normal Coronary Arteries. / G. Y. Lip, J. Gupta, M. Khan, S. P. Singh // Int J Cardiol. - 1995. - № 51. - P. 65-71.

5. Tun A. Acute Myocardial Infarction With Angiographically Normal Coronary Arteries / A. Tun, I. Khan // Heart Lung. - 2000. - № 29. - P. 48-50.

6. Khan I. A. Myocardial Infarction In A Pre-Menopausal Woman With Angiographically Normal Coronary Arteries / I. A. Khan, A. W. Ansari // Postgrad Med J. - 1998. № 74. - P. 671-672.

7. Myocardial Infarction And Normal Coronary Arteriography: A 10 Year Clinical And Risk Analysis Of 74 Patients / R. Raymond, J. Lynch, D. Underwood [et al.] // J Am Coll Cardiol. - 1988. - № 11. - P. 471-477.

8. Sharifi M. Myocardial Infarction With Angiographically Normal Coronary Arteries / M. Sharifi, T. Frohlich, I. Silverman // Chest . - 1995. - № 107. - P. 36-40.

9. Myocardial Infarction With Normal Coronary Arteries : A Prospective Clinical-Angiographic Study / A. Betriu, J. C. Pare , G. A. Sanz [et al.] // Am J CarDiol. - 1981. № 48. - P. 28-32.

10. Seven Year Survival Of Patients With Normal Or Near Normal Coronary Arteriograms: A Cass Registry Study / H. G. Kemp, R. A. Kronmal, R. E. Vliestra, R. L. Frye // Jam Collcardiol . - 1986. - № 7. - P. 479-83.

11. Myocardial Infarction With Minimal Coronary Atherosclerosis In The Era Of Thrombolytic Reperfusion / D. J. Kereiakes, E. J. Topol, B. S. George [et al.] // Jam ColIcardiol. - 1991. - № 17. - P. 304-312.

12. Lichtlen P. R. Long Term Prognosis Of Patients With Angina-Like Chest Pain And Normal Coronary Angio- graphic Findings / P. R. Lichtlen, K. Bargheer, P. Wenzlaff // J Am Collcardiol. - 1995. - № 25. - P. 1013-1018.

13. Early Thrombolysis In Acute Myocardial Infarction: Limitation Of Infarct Size And Im-Proved Survival / M. Simoons, P. Serruys, M. Van Der Brand [et al.] // J Am Coll Cardiol . - 1986. - № 7. - P. 717-728.

14. Acute Myocardial Infarction With Normal Coronary Arteries / S. D. Brecker, R. N. Stevenson, R. Roberts [et al.] // BMJ. - 1993. - № 307. - P. 1255-1256.

15. Lindsay J. Acute Mycocardial Infarction With Normal Coronary Arteries / J. Lindsay, A. D. Pichard // Am J Cardiol . - 1984. - № 54. - P. 902-904.

16. Coronary Vasospasm As A Possible Cause Of Myocardial Infarction: A Conclusion Derived From The Study Of Preinfarction Angina / A. Maseri, A. L'abbate, G. Baroldi [et al.] // N Engl J Med. - 1978. - № 299. - P. 1271-1277.

17. The Clinical Implications of Diabetic Heart Disease / R. Butler, T. M. Macdonald, A. D. Struthers, A. D. Morris // Eur Heart J. - 1998. - № 19. - P. 1617-1627.

18. Brief Report: Recognition Of Acute Myocarditis Masquerading As Acute Myocardial Infarction / J. Narula, B. A. Khaw, G. Dec [et al.] // N Engl J Med. - 1993. - № 328. P. 100-1004.

19. Spodick D. Infection And Infarction. Acute Viral (And Other) Infection In The Onset, Pathogenesis, And Mimickry Of Acute Myocardial Infarction / D. Spodick // Am J Med . - 1986. - № 81. - P. 661-668.

20. Myocardite Se Presentant Comme Infarctus Du Myocarde / J. Sztajzel, J. Reymond, J. Adamec, W. Rutishauser // Schweiz Med Wochenschr. - 1994. - № 124. P. 2026-2031.

21. Cigarette Smoking Is Associated With DoseRelated And Potentially Reversible Impairment of Endothelium-Dependent Dilatation In Healthy Young Adults / D. S. Celermajer, K. E. Sorensen, D. Georgakopoulos [et al.] // Circulation. - 1993. - № 88 (Part 1). P. 2149-2155.

22. Glasser S. P. Atherosclerosis: Risk Factors And The Vascular Endothelium / S. P. Glasser, A. P. Selwyin, P. Ganz // Am Heart J. - 1996. - № 131. - P. 379-384.

23. The Effects Of Acute And Chronic Cocaine Use On The Heart / R. A. Kloner, S. Hale, K. Alker, S. Rezkalla // Circulation . - 1992. - № 85. - P. 407-419.

\section{CLINICALCOURSE OF MYOCARDIAL INFARCTION WITH ANGIOGRAPHICALLY INTACT AND SLIGHTLY ALTERED CORONARY ARTERIES IN RESIDENTS OF MOUNTAIN AND PLAIN POINTS OF TRANSCARPATHIA}

๑O. V. Ustych

\section{SHEl «Uzhhorod National University»}

SUMMARY. There was analyzed the data of patients with myocardial infarction in the background and angiographically normal coronary arteries significantly altered the inhabitants of different regions of Transcarpathianregion. Highlanders were younger and had larger posterior wall of the left ventricle, right ventricle and left atrium. Mountain residents rarely sought medical help and often did not even treat in the presence of alarming symptoms of the cardiovascular system.

KEY WORDS: myocardial infarction, coronary artery intact, slightly altered coronary artery, mountain regions. 